\title{
Effects of oil pollution on seed germination and seedling emergence toxicity
}

\section{IONESCU ŢOPA SORANA ${ }^{1}$, SIMONA MIHĂILESCU ${ }^{2}$, DANIELA STRAT ${ }^{3}$, GHEORGHE IULIANA FLORENTINA**}

\author{
${ }^{1}$ Petroleum-gas University of Ploiesti, Bd Bucureşti 39, Ploieşti, 100680, Romania \\ ${ }^{2}$ Institute of Biology, Bucharest, Romanian Academy, Splaiul Independenţei 296, OP-CP \\ 56-53, 060031, Bucharest, Romania \\ ${ }^{3}$ University of Bucharest, Faculty of Geography, Bd N. Bălcescu 1, Sector 1, 010041 \\ Bucharest, Romania \\ ${ }^{4}$ Ecological University of Bucharest, Faculty of Natural Science and Ecology, Bd Vasile \\ Milea $1 \mathrm{G}$, Bucharest, Romania
}

\begin{abstract}
Oil spill represents the release of a liquid petroleum hydrocarbon (including its volatile fraction) into the environment, due to human activities like tankers, oil wells, off shore and terrestrial oil platforms. The goal of this paper was to identify potentially useful plant indicator species for ecological restoration and remediate of oil contaminated soils. The use of plant-based system to remediate contaminated soils has become an area of intense scientific study in recent years and it is apparent that plant which grow well in contaminated soils need to be identified and screened for use in phytoremediation technologies. Therefore, in this study the effect of crude oil on germination and seedling emergence of selected plant species was investigated.The objective was to determine if crude oil exerts detrimental effect to plants during early critical stages in their development. The detrimental effect growth was compared to the control after 14 days. Three grass species were tested: Festuca pratensis, Lolium perenne and Poa pratensis. We measured plant height, root length, and plant dry weight. Visual phyto-toxicity was also recorded in a laboratory experiment where seeds that germinated were photographed and morphological parts measured. In contaminated soil that was air-dried at $30^{\circ} \mathrm{C}$ and volatile compounds lost during the preparation of treatments, the inhibition effect was insignificant. The results indicate that the volatile compounds exert a significant inhibition effect on seed germination and seedling emergence compared tocrude oil. A concentration of $8 \mathrm{mg}$ oil/g soil determined a decrease of about $50 \%$ of the biomass and a concentration of $32 \mathrm{mg} \mathrm{oil} / \mathrm{g}$ soil a decrease of seed germination rate to about $50 \%$ for Poa pratensis. In this case the range $64-128 \mathrm{mg}$ oil $/ \mathrm{g}$ soil is critical to determine the EC50. The soil analyses indicated a content of sand (46\%), silt (46\%), clay (8\%), TN $(0.91 \pm 0.12 \mathrm{mg} / \mathrm{g}$ dry soil), TP $(0.26 \pm 0.08 \mathrm{mg} / \mathrm{g}$ dry soil), TK $(6.81 \pm 0.56$ (mg/g dry soil); anda higher pollution with Total Petroleum Hydrocarbons TPH (C10 - C40) (20 mg/g soil) at Țintea site.
\end{abstract}

Keywords Oil-contaminated zones, toxicity tests, seed germination, seedlings survival rate.

To cite this article: SORANA OT,, MIHĂILESCU S, STRAT D, FLORENTINA GI. Effects of oil pollution on seed germination and seedling emergence toxicity. Rom Biotechnol Lett. 2020; 25(1): 1194-1201. DOI: $10.25083 / \mathrm{rbl} / 25.1 / 1194.1201$ 


\section{Introduction}

Romania was one of the most important producers of petroleum products last century that placed it on $6^{\text {th }}$ place in the world in 1928. Prahova region recorded a yearly production of crude oil at that time of about 1475503 tons (CALCAN [1]; PIZANTY [2]), comparable to a yearly production of crude oil of 494240 tons for 2003 (INS [3]). Therefore, Prahova region was and still is the most affected area by oil pollution from Romania because of the spills from crude oil extraction areas (Băicoi, Boldeşti), chronic pollution from refineries (eight are still functional now), destruction caused by bombardments during World War II, transport pipeline deterioration, discharge of waste waters from refineries etc. In these areas, the ground-polluted layer is about 4-6 $\mathrm{m}$ depth from the topographic surface and the thickness of the oil layer range in time and space from 0.01 to $3 \mathrm{~m}$ (***[4]; APMPRAHOVA REPORT [5]; [6]). Oil polluted vegetation can be perturbed for a long time. These perturbations are not only determined by the amount of oil and retention rates, but also by shifts in competitive interactions and consequent shifts in vegetation structure. Experimental studies have shown that species that respond in an opportunistic way (potential for recovery) become dominant and suppress the recovery of the other species. For example, vigorous growth of Puccinellia, following oil spills in the field, can be explained by changed competitive interactions which favour it. Festuca and Plantago respond differently to oil pollution when growing with different assemblages of species (** [7]; SCHOLTEN\&al. [8]; SCHOLTEN \& LEENDERTSE [9]). Phytotoxicity was seen to increase with gravity through the series gasoline, kerosene, diesel fuel and heavy oil, indicating that the lighter fractions either because they were more volatile or because the compounds present were less toxic, caused less long term damage to the plants than heavier fraction. Highly volatile hydrocarbons, primarily those that are small and lightweight, are able to move through cell membranes easily. Small hydrocarbon molecules, which penetrate into the plant, can cause toxic effects, which although acute, are generally short lived (*[10]; ADAM\& DUNCAN [11]; LU \& al [12]; MANZO [13]; ADIEZE \& al [14]). For example, germination of seeds in diesel fuel contaminated soil is highly dependent on plant species. The ability to tolerate diesel fuel contamination was species specific, members of the same plant family showing differential sensitivity to diesel fuel. For the more tolerant plant species, a delay in seed emergence was generally observed (ADAM \& DUNCAN [11]). Plants have been shown to encourage organic contaminant degradation principally by providing an optimal environment for microbial proliferation in the rhizosphere. In the rhizosphere, processes determining transport and bioavailability of organic substrates are more complex than in unvegetated soils. Different types of plants are effective at stimulating the degradation of organic molecules in the rhizosphere. Typically, these plants all have extensive and fibrous roots, which form an extended rhizosphere. The high concentration of bacteria around the roots, in the rhizosphere, presumably occurs because of the presence of high levels of nutrients that are exuded from the roots of most plants and can then be used to support bacterial growth and metabolism (GUNTHER [15]; KULAKOW \& ERICKSON [16]; TESAR [17]; GLICK [18]). If plants can be successfully established on polluted soils, then the plant microbial interaction in the rhizosphere may provide enhanced breakdown of hydrocarbons in vegetated soils as opposed to non-vegetated soils (ADAM \& DUNCAN [11]; TESAR [17]; TISCHER\& HUBNER [19]). Usually, grasses are used in remediation of contaminated soil due to their fibrous root systems with extensive surface area available for microbial colonisation. The fibrous root system forms a continuous, dense rhizosphere, which provides ideal conditions for phytoremediation. Types and amount of hydrocarbons presented in the soil are important for bioremediation. Freshly spiked soil was reported to be more toxic to plants and microorganisms than aged contamination, where pollutants are in general adsorbed to a higher degree on soil particles and therefore less available for degradation (KULAKOW \& al [20]; TESAR \& al [21]; GOGOI \& al [22]). Low molecular weight components, which are more toxic than higher molecular weight hydrocarbons, are evaporated or degraded more easily, so that the toxicity of weathered oil is, reduced (LIN \& MENDELSSOHN [23]). At the same time, the apparent recalcitrance of petroleum hydrocarbons fractions may be due beside the lack of bioavailability by the lack of requisite oxidizing enzymes and toxicity to soil microorganisms (SALANITRO \& al [24]). Target components in oil-polluted soils are polycyclic aromatic hydrocarbons (PAHs). They present a great affinity for soil organic materials, are very stable compounds and the initial oxidation step is biologically slow and metabolically expensive. Relatively few microorganisms can use high molecular weight PAHs as a sole carbon source. Thus, microbial remediation alone is probably too slow. Enhanced remediation of soil PAHs in the presence of plants has been reported. The basic mechanisms involved remain poorly understood, and there still exist a lack of information on the contribution of plant uptake of soil PAHs and their translocation behaviours have not been defined yet. However, for remediation to be effective, the overall rate of PAH removal and degradation must be accelerated and one way to facilitate this is by increasing the amount of biomass in contaminated soil using higher plants (GLICK [18]; GAO \& ZHU [25]; HUANG \& al [26]; [27]). Besides crude oil type and concentration of Total Petroleum Hydrocarbons (TPH), differences in the extent of soil hydrocarbon biodegradation may depend upon soil types and nutrient growth stimulants (SALANITRO \& al [24]). Though at present not many details are known about the influence of soil type on biodegradation kinetics, it is likely that the high sorptive surfaces of some clay and organic matter fractions limit the bioavailability of petroleum hydrocarbons to soil microorganisms. This may be especially the case for intensely degraded soils where the contaminants have had time to migrate into the 
micropores, which are less accessible to microbial attack. Moisture content the in soil is important because it has relevance to the biodegradation process (GOGOI \& al [22]).

Regarding the clean-up of soils, there are no universal TPH cleanup standards for soils contaminated with fresh or weathered crude oils. State guidelines developed mainly for oil product spills to surface or subsurface soils have varying end points such as 10-10 000 mg/kg TPH and differences of as much as tenfold $(10-100 \mathrm{mg} / \mathrm{kg})$ were observed for PAH clean up standards (SALANITRO \& al [24]; DORN $\&$ al [28]). Consequently, there is a need to develop environmentally acceptable endpoints for soil quality and the use of biological endpoints to evaluate waste site contamination compared to arbitrary chemical criteria clean up levels is welcome and may be incorporated into risk based corrective action for waste sites. The goal of the present study was to quantify the negative effects of crude oil on germination and seedling emergence onthree herbaceous plant species, abundant in a historically highly oil contaminated area. The attention was focused on two main aspects:

1. There are differences between seeds of $F$. pratensis collected from polluted area and seeds obtained from a commercial supplier?
2. There is any difference regarding the seed germination due to due to the way the treatments were prepared? (comparing air-dried soil at $30^{\circ} \mathrm{C}$ and non air dried soil).

\section{Materials and Methods}

\section{Field description}

During the World War I in the Prahova area were destroyed by command 1677 oil wells, 26 refineries and many tanks and manufactories. Then, during World War II the Ploieşti town and its surroundings was an important target of the air raids, during which the most parts of the industrial objectives were destroyed. All these historical events caused heavy oil pollution in the area and the nowadays contaminated zones (especially groundwater pollution) correspond to the old industrial objectives destroyed.The oldest oil field in the Prahova area was recorded in 1785 and the first refinery was built at Rifov in 1856. In 1862, the first well for oil extraction was built in Prahova region. The Prahova region was and still is one of the most affected areas by oil pollution from the country (GHEORGHE \& al [29]). The study site is located at Țintea $\left(44^{\circ} 55^{\prime} 3.05^{\prime \prime} \mathrm{N} ; 26^{\circ} 1^{\prime} 57.11^{\prime \prime} \mathrm{E}\right)$, one of the oldest oil field from the Prahova Sub Carpathians area and Romania where some of the oil well are still operating (Fig. 1).

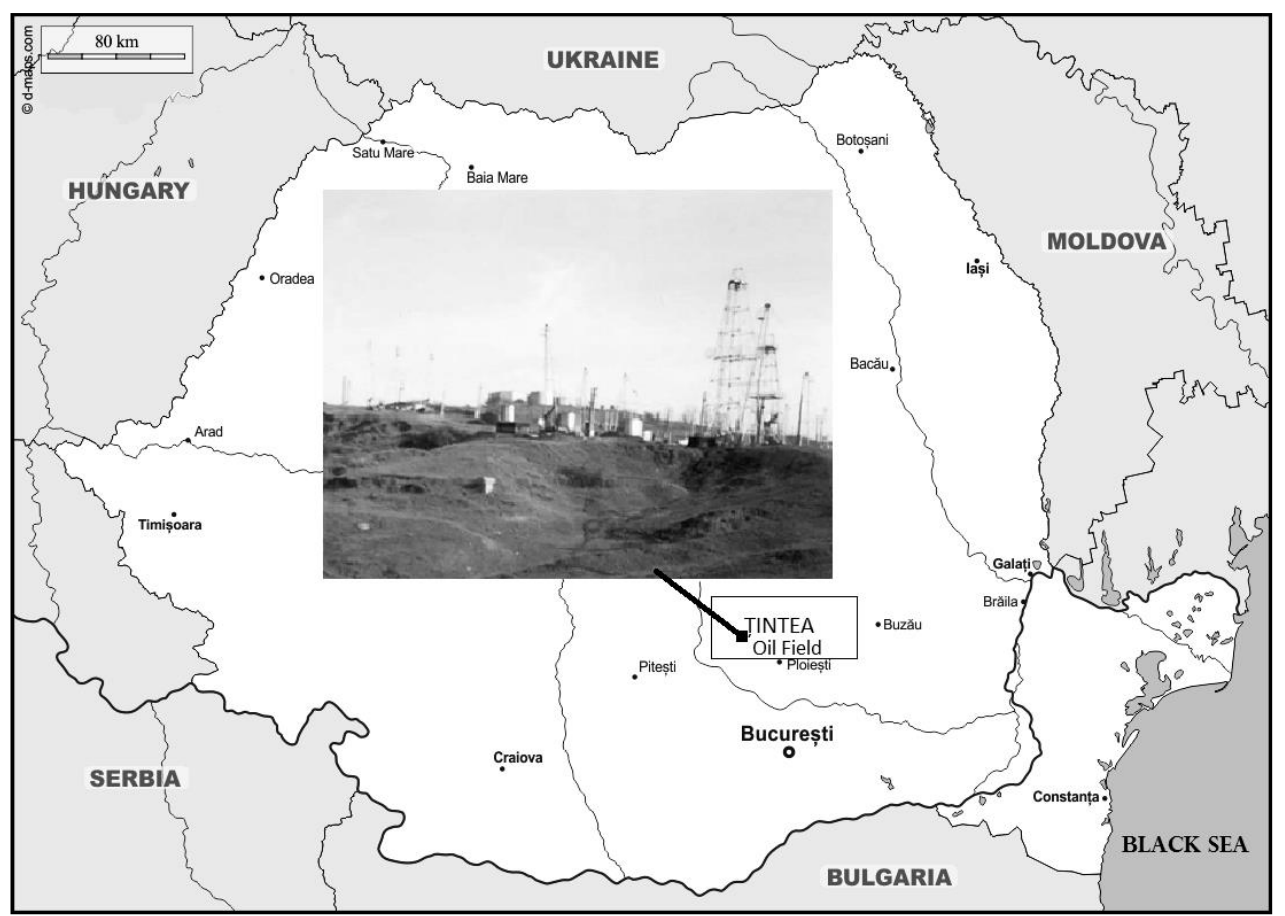

Figure 1. Geographical position of the study site (left) and the general view of the Ţintea oil field.

\section{Laboratory experiments}

Three plant species were used for tests: Festuca pratensis, Lolium perenne and Poa pratensis (with seeds supplied by Barenbrug Holland Company). For F. pratensis we also used seeds collected from Thintea site (the seeds being taken late autumn from vigorous individuals in order to be mature. Seeds for ecotoxicity tests were sorted by size and health state and prepared for germination experiments. Several trials were made in order to find the optimum conditions for seed germination. Seeds of $F$. pratensis collected in Romania requested a pre-treatment (stratification for four weeks at $4{ }^{\circ} \mathrm{C}$ ). To determine TPH concentration in soil at Tintea site, 35 soil samples (5 replicated for each concentration) were collected and sent to Utrecht University for granulometry (sand, silt, clay proportion), hydrocarbon and nutrients (Total Nitrogen, Total Phosphorus and Total Potassium content (PAUL \& al [30]) analyse performed by laboratory of Institute of Risk 
Assessment Studies, Utrecht University. For toxicity tests a medium crude oil (API 33) from Țintea exploitation area was used. Therefore, for the experiments performed we used the following concentrations: Control (C0), $0 \mathrm{mg}$ crude oil/g soil, $4 \mathrm{mg} / \mathrm{g}(\mathrm{C} 1), 8 \mathrm{mg} / \mathrm{g}$ (C2), $16 \mathrm{mg} / \mathrm{g}$ (C3), $32 \mathrm{mg} / \mathrm{g}$ (C4),64 mg/g (C5), $128 \mathrm{mg} / \mathrm{g}$ (C6), $256 \mathrm{mg} / \mathrm{g}$ (C7). The experimental soil has been sterilized, kept at $105^{\circ} \mathrm{C}$ for 24 hours to remove the microorganisms and divided into two types of samples. Then, the samples were rehydrated with sterile water. In half of them, the crude oil was added drop wise to the wet soil and mixed on a magnetic stirring until the oil was thoroughly and evenly mixed into the soil and half were kept as control samples. After that the mixed soil was put in Petri dishes, dried at $30^{\circ} \mathrm{C}$ and weighted, except for the $P$. pratensis reatments, where the Petri dishes have not been air-dried. Before to start of the experiments, distillate water was added to each Petri dishuntil the soil humidity reached $30 \%$. During the experiments the soil in the Petri dishes was moistened when were necessary and the number of seed germinated recorded daily. Eight experiments were set up. A number of six replicates were used for each treatment and 30 seeds were placed in each Petri dish (a total number of 1440 seeds for each species). Seeds were separated into size classes and they were used seeds from the most numerous class. All Petri dishes were placed in a growth chamber to light conditions at $20^{\circ} \mathrm{C}$ with a $16 \mathrm{~h}$ light $/ 8 \mathrm{~h}$ dark cycle, and $70 \%$ humidity. Seed germination, root elongation and seedling emergence toxicity test have been done according to procedures developed in EPA guidelines (EPA 712-C-96-154 [31]; EPA 712-C-96-153 [32]). Seed germination rate was determined after 14 days. Parameters measured include plant height; root length and plant dry weight. Visual phyto-toxicity was also recorded in a laboratory experiment where they were followed, seeds that germinate, by photographing and measuring morphological parts using millimeter paper. Morphological changes, depigmentation and chlorosis were observed through the analysis of the photographs. Also, root dimensions were measured using millimeter paper. For all the seedlings were taken photos and UTHSCSA Image Tool software was used to measure the length of leaves and roots. The primary root should attain a length of $5 \mathrm{~mm}$ for the seed to be counted as having germinated. Toxic effects are reported as percent of seed germination and percentage growth inhibation.

\section{Results and Discussions}

\section{Seed germination and seedling emergence toxicity tests}

The texture and chemical characteristics of the experimental soil used in laboratory were: sand (46\%), silt $(46 \%)$, clay $(8 \%)$, TN $(0.91 \pm 0.12 \mathrm{mg} / \mathrm{g}$ dry soil $)$, TP $(0.26 \pm 0.08 \mathrm{mg} / \mathrm{g}$ dry soil), and TK $(6.81 \pm 0.56$ (mg/g dry soil) .The previous results showed that the maximum TPH concentration in soil at Ţintea site was $20 \mathrm{mg} / \mathrm{g}$ soil. In both experiments, the germination rate was high up to $64 \mathrm{mg}$ oil/g soil and comparable with control treatment. Similar results were obtained for L. perenne (Fig. 2). This may be due to the fact that the volatile fractions of crude oil were lost by drying the soil at $30^{\circ} \mathrm{C}$. The previous research done on this subject underline that volatile fraction played an influential role in delaying seed emergence but remained fraction in soil addedd to this inhibitory effect on germination by physically impeding water and oxigen transfer between the seed and surrounding soil environment.

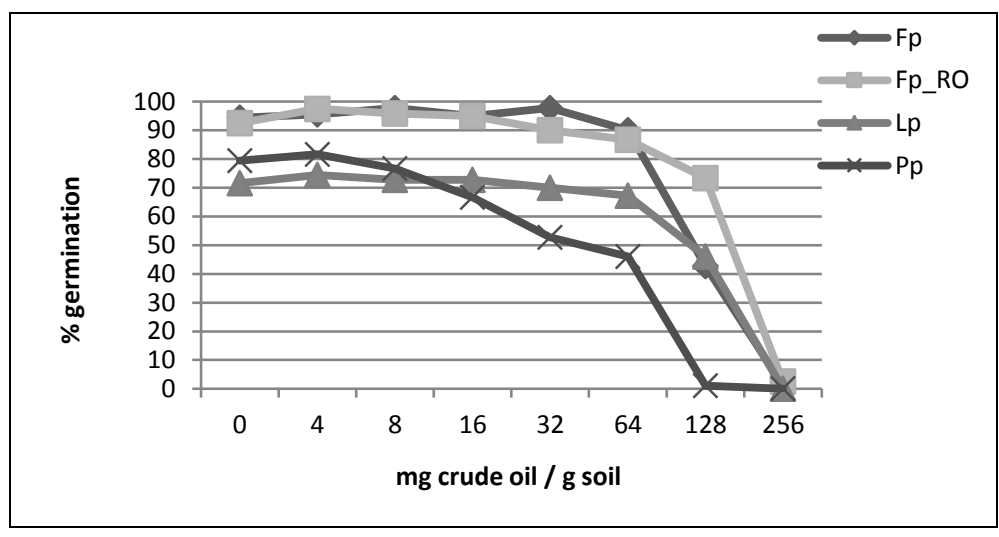

Figure 2. Percentage of seeds germination after 14 days (Fp - Festuca pratensis, Fp_RO - Festuca pratensis, Romania (Ţintea Site), Lp- Lolium perenne, Pp- Poa pratensis).

A higher concentration of crude oil (> $64 \mathrm{mg}$ oil/g soil) made the difference between the seeds collected from polluted area and seeds supplied by the Dutch company. Both $F$. pratensis and L. perenne seeds had similar germination rate, less than $50 \%$ (42\% and respectively $46 \%$ ) for a concentration of $128 \mathrm{mg}$ oil/g soil. For such high oil concentration in soil, seeds collected from polluted area still recorded a high germination rate $(73 \%)$. It seems that seeds from polluted area are more tollerant to high levels of pollution. Regarding the biomass data, excepting the $P$. pratensis experiment where a decrease of about $50 \%$ of biomass were recorded at $8 \mathrm{mg}$ oil $/ \mathrm{g}$ soil, for the other three experiments a similar trend was observed and the biomass was reduced to about $50 \%$ at a concentration around $128 \mathrm{mg}$ oil/g soil (Fig. 3). This may be due both to the differences between the species and to the effect of volatile compounds. 


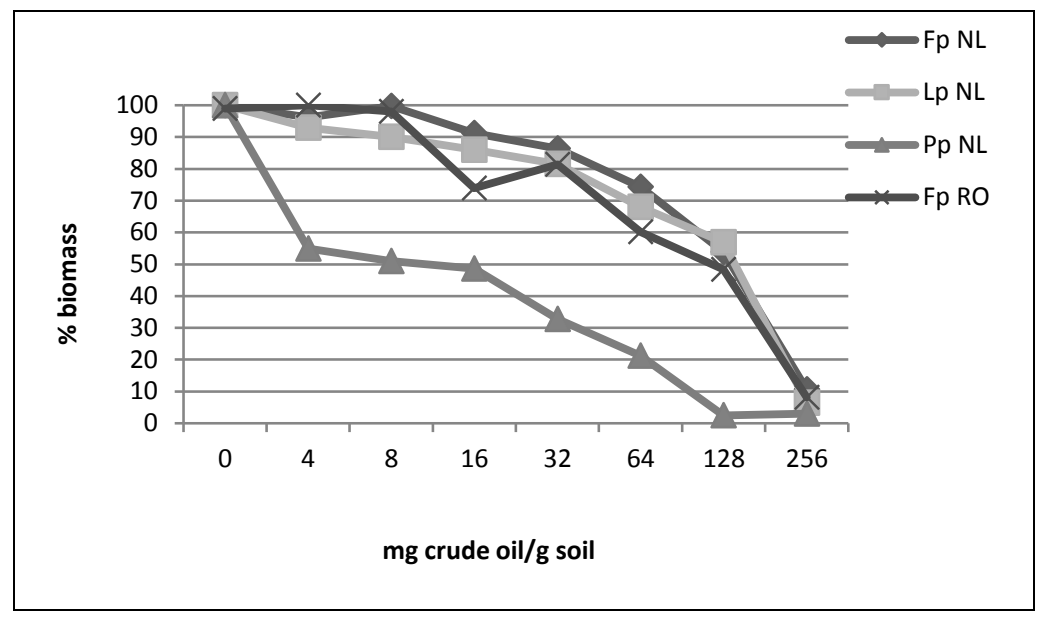

Figure 3. Biomass of the seedlings after 14 days.

The results obtained suggest that the range $64-128 \mathrm{mg}$ $\mathrm{oil} / \mathrm{g}$ soil is critical to determine the EC50. Regarding $P$. pratensis, a slowly and continuous decreases on germination rate as crude oil concentration increases can be observed. The germination rate was less than $50 \%$ for a concentration of $64 \mathrm{mg}$ oil/g soil (half of the concentration that caused a similar effect on F. pratensis and L. perenne). Results suggest the volatile fraction of crude oil played an important role in delaying seed emergence and reducing percentage germination, what was found to be obviously for P. pratensis (Fig. 4). Another experiment with seeds of $P$. pratensis germinating on air-dried soil would have been necessary to compare the effects of air-dried and non-air dried soil both based on the previous research done on this subject we assume that a similar trend would happen as we obtained for $F$. pratensis and L. perenne.

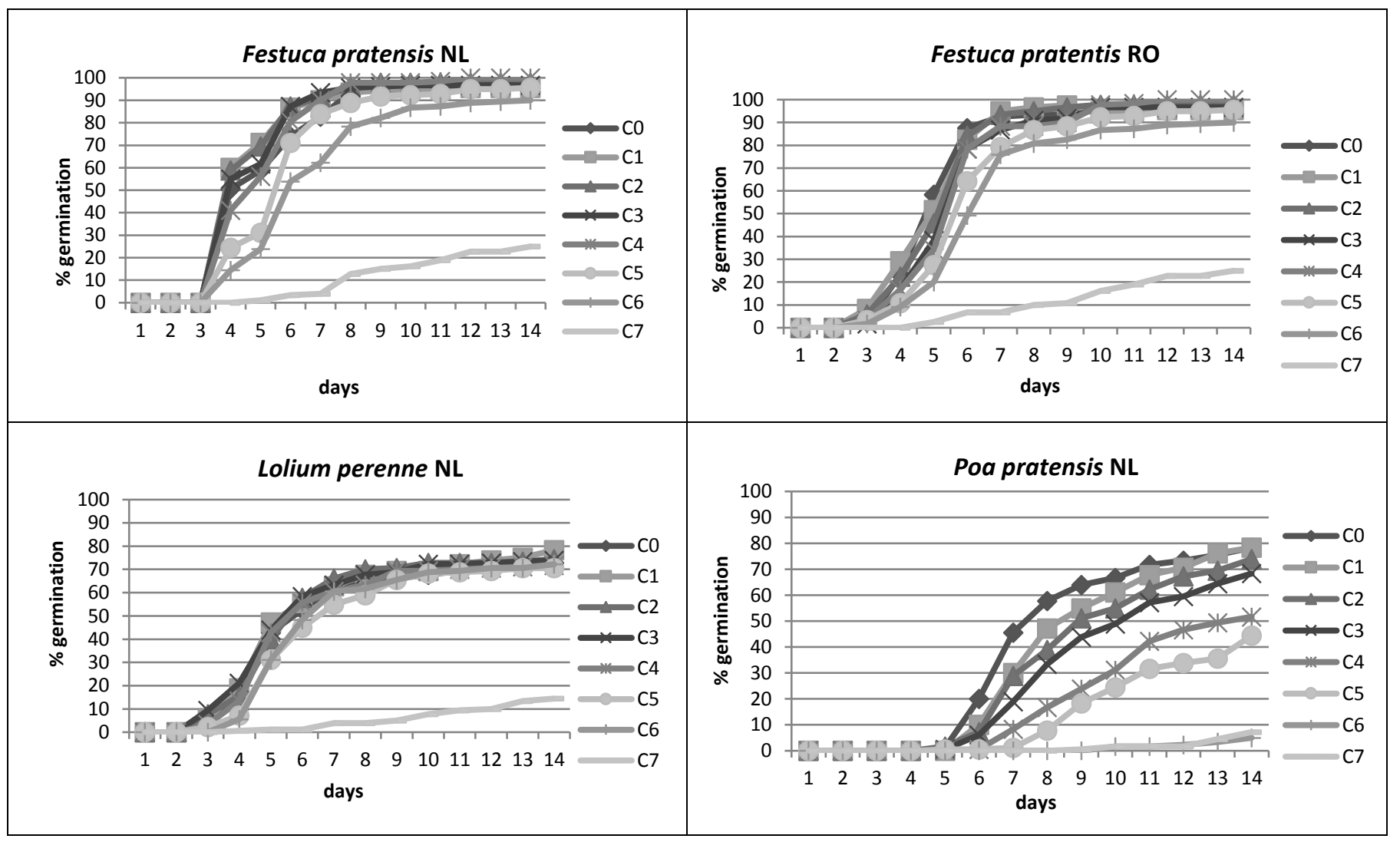

Figure 4. Seed germination dynamic during the 14 days of the experiment. 


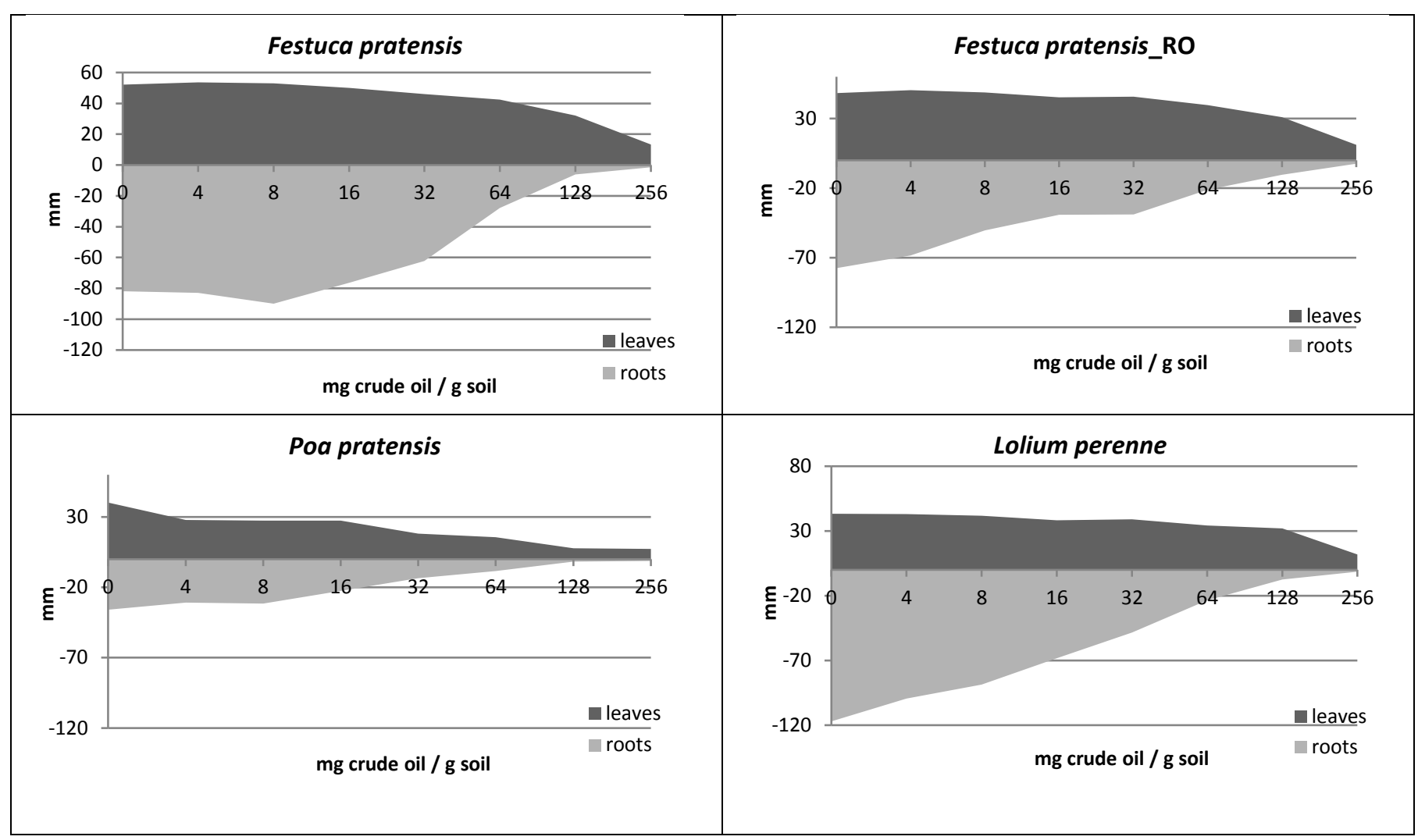

Figure 5. Dynamic of plant height and root elongation expressed in $\mathrm{mm}$.

The experiments with $F$. pratensis indicate that are no significant differences regarding germination rate. Comparing the results obtained for $F$. pratensis from polluted area and non-polluted area, there is a significant difference between biomass values for the same rate of germination. Seedlings from polluted area produced half of the biomass of the seedlings obtained from seeds supplied by the Dutch company. On one hand, this might be due to the size of the seeds $(2.5 \pm 0.5 \mathrm{~mm})$, which was bigger compare to seeds collected from Romania $(1.5 \pm 0.25 \mathrm{~mm})$, and therefore the nutritive reserve higher. On the other hand, the reduced biomass may be a stress response of $F$. pratensis population from Romania to a long-term pollution in that area. The results obtained correspond to the measurements made in the field, where a low biomass was measured. Plant height and root elongation results are presented in Fig. 5. The inhibition effect on root elongation can be observed for all species. An interesting aspect is that for crude oil concentration higher than $8 \mathrm{mg} / \mathrm{g}$ roots did not penetrate and preferred to develop at the surface of the soil (Fig. 6).
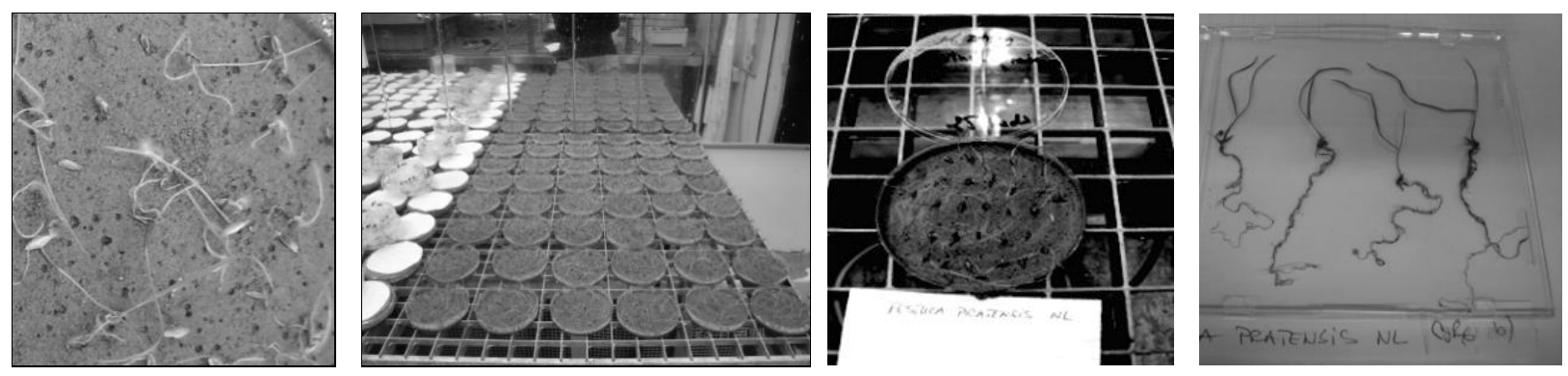

Figure 6. The roots not penetrate deep into the soil; they prefer to develop at the surface.

Visual phyto-toxicity effect was noticed for L. perenne, a high percent of yellow leaves (almost $80 \%$ affected by chlorosis) was assessed, and the size of the roots reduced by half.

\section{Conclusion}

The soil analyses indicated a higher pollution with Total Petroleum Hydrocarbons TPH (C10 - C40) at Țintea site; the large parts of these are polycyclic aromatic 
hydrocarbons (PAHs). The results indicate that the volatile compound exerts a significant inhibition effect on seed germination and seedling emergence. A concentration of $8 \mathrm{mg}$ oil $/ \mathrm{g}$ soil determined a decrease of about $50 \%$ of the biomass and a concentration of $32 \mathrm{mg}$ oil/g soil a decrease of seed germination rate to about $50 \%$ for Poa pratensis. In contaminated soil that was air-dried at $30^{\circ} \mathrm{C}$ and volatile compounds lost during the preparation of treatments, the inhibition effect was insignificant. In this case the range $64-128 \mathrm{mg}$ oil/g soil is critical to determine the EC50. Therefore, further investigations to identify types of hydrocarbons presented in soil are needed, since the degradation rate is determined by the complexity of their molecules and the age of contamination. An important target for future research is the identification of polycyclic aromatic hydrocarbons (PAHs) because one potential for PAHs release is from oil fields where production pits contain a mixture of crude oil, corrosion inhibitors, de-emulsifying chemicals, and salt water. Therefore, for a better understanding of the biodegradation and phytoremediation processes from soil, we would recommend for the Tintea site, where the level of pollution is high to extend the research in the future in order to make a more detailed analysis, as for example a chromatographic analysis of the saturated fraction of the extracted oil samples which can provides a semi-quantitative estimate of the extent of biodegradation. Regarding Țintea area we confront both, with new and old pollution (is one of the oldest oil fields from the region) but at the same time there is a permanent leaching of petroleum products from old pipes existing in the area. Therefore, further investigations to identify types of hydrocarbons presented in soil are needed, since the degradation rate is determined by the complexity of their molecules and the age of contamination. An important target for future research is the identification of polycyclic aromatic hydrocarbons (PAHs) because one potential for PAHs release is from oil fields where production pits contain a mixture of crude oil, corrosion inhibitors, de-emulsifying chemicals and salt water. Among hydrocarbons, (PAHs) have been recommended as priority pollutants by the United States Environmental Protection Agency (USEPA) and are target components for study in oil-contaminated sites due to their carcinogenic, mutagenic and toxic properties (BARTON \& al [33]; DUGAY \& al [34]; KE \& al [35]; MAILA \& CLOETE [36]; GAO \& ZHU [25]; HUANG \& al [26]; HE \& al [37]; LIU \& al [38]).

This preliminary research might support an extensive project for evaluation of the soil quality and bioremediation processes (biodegradation and phyto-remediation) for the Țintea site, Prahova area - Romania, in both laboratory and field experiments.

\section{Acknowledgements}

Results obtained within NWO Fellowship program (Cooperation between Oil-Gas University, Ploiești Department of Engineering Environmental Protection and University Utrecht, Department of Geo-Biology, Section Landscape Ecology) to SI. Many thanks for Prof. Dr. Jos Verhoeven for supervising the study and for the entire support during my stage at the Landscape Department Utrecht University. Thanks to seeds Supplier Company, BARENBRUG Holland, for providing free of charge the required seeds. Dr. M. Jonker and Dr. J. Hermens (IRAS, Utrecht University), and Dr. T.L. Pons (Faculty of Biology, Utrecht University) provided valuable advice and support during the project.

\section{References}

1. G. CALCAN, Industria petrolieră din România în perioada interbelică. Editura Tehnică, Bucureşti, 1997.

2. M. PIZANTY, Situaţia României în comerţul mondial de petrol. Institutul economic românesc. Cartea Românească, Bucureşti, 1936.

3. INS (NATIONAL INSTITUTE OF STATISTICS) http://www.insse.ro/cms/en, 2007.

4. ***Guidelines for land-treating petroleum hydrocarbon contaminated soils, Soil and Sediment Contamination, 1994.

5. APM PRAHOVA, 1995. Oil pollution of soil and groundwater in the area located south-east of Ploieşti, 1995. Environmental Protection Agency, Prahova County Report www.anpm.ro, 2010.

6. APM PRAHOVA, Environmental Protection Agency, Prahova County, 2010, Environment report. www.anpm.ro, 2010.

7. **Tasks for Vegetation Science http://www.springer.com/series/661

8. M. SCHOLTEN, P. LEENDERTSE, P.A. BLAAUW, The Effects of Oil Pollution on Interacting Salt Marsh Species, J. KUIPER, W.J. VAN DEN BRINK, eds., Fate and Effects of Oil in Marine Ecosystems, Springer, Berlin, 1987, pp. 225-228.

9. M. SCHOLTEN, P. LEENDERTSE, The impact of oil pollution on salt marsh vegetation, J. Rozema, J.A.C. VERKLEIJ, eds., Ecological responses to environmental stresses. Task for vegetation science, vol. 22, Springer, Dordrecht, 1991, pp. 184-190.

10. * https://theses.gla.ac.uk/\#

11. G. ADAM, H. DUNCAN, Influence of diesel fuel on seed germination. Environmental Pollution, 120 (2), 363, 370, 2000.

12. M. LU, Z. ZHANG, S. SUN et al, The Use of Goose grass (Eleusine indica) to Remediate Soil Contaminated with Petroleum, Water Air and Soil Pollution, 209 (1-4), 181, 189, 2010.

13. S. MANZO, Assessment of the effects of soil PAH accumulation by a battery of eco-toxicological tests. Chemosphere, 71(10), 1937, 1944, 2008.

14. I.E. ADIEZE, IFECHUKWU E., JUSTINA C. ORJI, ROSE N. NWABUEZE G.O.C. ONYEZE, Hydrocarbon stress response of four tropical plants in weathered crude oil contaminated soil in microcosms, International Journal of Environmental Studies, 69(3), $1,11,2012$.

15. T. GUNTHER, Effects of ryegrass on biodegradation of hydrocarbons in soil. Chemosphere, 33(2), 203, 215, 1996. 
16. P.A. KULAKOW, L. ERICKSON, A nationwide field test of petroleum-contaminated soils. Proceedings of the 2000 Conference on Hazardous Waste Research, Denver, Colorado, May 23-25, 283, 298, 2000.

17. M. TESAR, Bacterial rhizo-sphere populations of black poplar and herbal plants to be used for phytoremediation of diesel fuel. Soil Biology and Biochemistry, 34(12), 1883, 1892, 2002.

18. B.R. GLICK, Phytoremediation: synergistic use of plants and bacteria to clean up the environment. Biotechnology Advances, 21, 383-393, 2003.

19. S. TISCHER, T. HUBNER, T., Models trials for phytoremediation of hydrocarbon contaminated sites by the use of different plant species. International Journal of Phytoremediation 4(3), 187, 203, 2002.

20. P.A. KULAKOW, A.P. SCHWAB, M.K. BANKS, Screening plants species for growth on weathered, petroleum hydrocarbon-contaminated sediments. International Journal of Phytoremediation, 2(4), 297, 317, 2000.

21. M. TESAR, T.G. REICHENAUER, A. SESSITSCH, Bacterial rhizosphere population of black poplar and herbal plants to be used for phytoremediation of diesel fuel. Soil Biology \& Biochemistry, 34, 1883, 1892, 2002.

22. B.K. GOGOI, N.N. DUTTA, P. GOSWAMI, T.R.K. MOHAN, A case study of bioremediation of petroleum-hydrocarbon contaminated soil at a crude oil spill site. Advances in Environmental Research, 7, 767, 782, 2003.

23. Q. LIN, I.A. MENDELSSOHN, The combined effects of phyto-remediation and bio-stimulation in enhancing habitat restoration and oil degradation of petroleum contaminated wetlands. Ecol. Eng., 10, 263, 274 (1998).

24. J.P. SALANITRO, P.B. DORN, M.H. HUESEMANN, K.O. MOORE, I.A. RHODES, L.M. RICE JACKSON, T.E. VIPOND, M.M. WESTERN, H.L. WISNIEWSKI, Crude oil bioremediation and soil ecotoxicity assessment. Environmental Science \& Technology, 31(6), 1769, 1776, 1997.

25. Y. GAO, L. ZHU, Plant uptake, accumulation and translocation of phenanthrene and pyrene in soils. Chemosphe 55, 1169, 1178, 2004.

26. X-D. HUANG, Y. EL-ALAWI, D.M. PENROSE, B.R. GLICK, B.M. GREENBERG, B.M., A multi-process phytoremediation system for removal of polycyclic aromatic hydrocarbons from contaminated soils. Environmental Pollution, 130 (3), 465, 476, 2004.

27. X-D. HUANG, Y. EL-ALAWI, J. GURSKA, B.R. GLICK, B.M. GREEENBERG, A multi-process phytoremediation system for decontamination of persistent total petroleum hydrocarbons (TPHs) from soils. Microchemical Journal, 81 (1), 139, 147, 2005.

28. P.B. DORN, T.E. VIPOND, J.P. SALANITRO, H.L. WISNIEWSKI, Assessment of the acute toxicity of crude oils in soils using earthworms, microtox, and plants. Chemosphere, 37(5), 845, 860, 1998.

29. I.F. GHEORGHE, S. IONESCU (ŢOPA), D. STRAT, Effects of oil pollution on vegetation, potentially useful indicator species for rehabilitation. Romanian Biotechnological Letters, 24(1), 2018.

30. E.A. PAUL, H.P. COLlins, S.W. LEAVITT, Dynamics of resistant soil carbon of mid western agricultural soils measured by naturally occurring C-14 abundance. Geoderma, 104, 239, 256, 2001.

31. EPA 712-C-96-154, Ecological effects test guidelines. OPPTS 850.4200 Seed Germination/ Root Elongation Toxicity test, 1996.

32. EPA 712-C-96-153, Ecological effects test guidelines. OPPTS 850.4100 Terrestrial Plant Toxicity, Tier I (Seedling Emergence), 1996.

33. L.L. BARTON, B.M. THOMSON, G.S. BROWN, Strategies for remediation of sites containing polyaromatic hydrocarbons (PAHs). Technical Completion Report. New Mexico Werc, a Consortium for Environmental Educational and Technology Development in cooperation with U.S. Department of Energy, 2000.

34. A. DUGAY, C. HERRENKNECHT, M. CZOK, F. GUYON, N. PAGES, New procedures for selective extraction of polycyclic aromatic hydrocarbons in plants for gas chromatographic-mass spectrometric analysis. Journal of Chromatography A, 958, 1, 7, 2002.

35. L. KE, T.W.Y. WONG, Y.S. WONG, N.F.Y. TAM, 2002. Fate of polycyclic aromatic hydrocarbon (PAH) contamination in a mangrove swamp in Hong Kong following an oil spill. Marine Pollution Bulletin 45 (1-12), 339, 347, 2002.

36. M.P. MAILA, T.E. CLOETE, Germination of Lepidium sativum as a method to evaluate polycyclic aromatic hydrocarbons (PAHs) removal from contaminated soil. International Biodeterioration \& Biodegradation, 50, 107, 113, 2002.

37. H-W. HE, H. PENG, X-S.TAN,General Methodology, H-W.HE, H. PENG, X-S.TAN, eds., Environmentally Friendly Alkyl-phosphonate Herbicides, Springer, Berlin, 2014, pp. 391-444.

38. R. LIU, R.N. JADEJA, Q. ZHOU, Z. LIU, Treatment and remediation of petroleum-contaminated soils using selective ornamental plants, Environmental Engineering Science, 29 (6), 494, 501, 2012. 